Article

\title{
Socioeconomic Assessment of Meat Protein Extracts (MPE) as a New Means of Reducing the U.S. Population's Salt Intake
}

\author{
Bedanga Bordoloi *, Rikke Winther Nørgaard, Flemming Mark Christensen and \\ Per Henning Nielsen \\ Novozymes A/S, Krogshoejvej 36, Bagsvaerd 2880, Denmark \\ * Author to whom correspondence should be addressed; E-Mail: bgbd@novozymes.com; \\ Tel.:+45-4446-0241; Fax: +45-4446-9999.
}

Received: 5 January 2012; in revised form: 13 March 2012 / Accepted: 27 March 2012 /

Published: 29 March 2012

\begin{abstract}
Excessive salt intake causes a number of cardiovascular diseases, such as strokes and hypertension. This is a burden on the individual as well as on society, because these diseases are fatal and costly to treat and live with. Much of the salt comes from processed meat such as sausages, ham, and bacon and has, so far, been hard to avoid because of consumer taste preference as well as the technological benefits. Meat protein extract (MPE) is a broth of hydrolyzed protein which can reduce the salt in processed meat by more than one third without compromising on taste and functionality. This study estimates the socioeconomic impacts of implementing MPE widely across the United States (US) by relating the national salt intake reduction potential of MPE (5\%) to a broad range of health, societal, and individual factors derived from the literature. Results show that benefits for society are substantial and MPE could be part of the solution for the problem of excessive salt intake. MPE could deliver $25 \%$ of the U.S. 'National Salt Reduction Initiative' goals, avoid approximately 1 million hypertension cases and save around USD 1.6 billion in annual direct healthcare costs. Verification indicates that these estimates are conservative.
\end{abstract}

Keywords: salt; sodium; shared value; meat ;enzyme; healthcare; QALY; chronic diseases 


\section{Introduction}

Salt has been used as a food preservative for thousands of years [1]. With the invention of the refrigerator, salt is no longer required to the same extent as a preservative, and is now used more as a taste enhancer [2]. As time has increasingly become a scarce resource in many parts of the world, the consumption of processed food with a high salt content to save time on home cooking has increased extensively [1]. Salt used in food products is a mixture of sodium and chloride. Excessive sodium has a range of adverse effects on health, and many studies have been conducted on the recommended sodium intake level [3-5]. Results show that, in order to prevent chronic diseases, the average per capita consumption of sodium should be below $2 \mathrm{~g}$ /day. Average sodium intake exceeds this recommended amount [6], contributing to common chronic diseases such as obesity, diabetes, hypertension, and cardiovascular diseases [7-9]. These diseases not only have a significant negative effect on people's lives, but also on society, as extensive resources are used by healthcare systems for treatment [10,11].

Population-based strategies have been used across the world [12] to lower salt content in food products. The National Salt Reduction Initiative (NSRI), introduced by New York City Health Department in 2010, is an example of a national coalition of health authorities and organizations working to help food manufacturers and restaurants to reduce the amount of salt in food products on a voluntary basis. The goal is to reduce the salt intake of Americans by $20 \%$ by 2014 [13]. The common objective of population-based strategies is to reduce the average dietary salt intake from processed foods through voluntary actions by companies, organizations and government regulation [12,14].

Processed meat (sausages, ham, bacon etc.) is the second largest source of sodium intake (18\% of daily sodium intake) in the US [6]. Several methods exist for reducing sodium levels in processed meat. One is to reduce the actual salt content. However, only small gradual reductions in salt content in the range of 5-10\% can be implemented without compromising on taste and texture. Larger reductions require reformulation of the products to ensure flavor and aroma [2]. Another method is to use salt replacers, where sodium salt $(\mathrm{NaCl})$ is replaced with potassium salt $(\mathrm{KCl})$ for instance. However, potassium salt has a metallic off-taste, and potassium can only replace a certain fraction of the sodium without compromising on taste. Finally, salt perception can be improved by modifying the $\mathrm{NaCl}$ crystal structure or by adding salt enhancers to the meat to restore the sensation of saltiness [2]. However, none of the methods suggested so far have the potential to solve the entire excess sodium intake problem within processed meat, and there is a need for a broader choice of salt reduction opportunities.

Meat Protein Extracts (MPE) is one such opportunity. MPE is a tasty protein soup or broth which is produced by hydrolyzing the meat that remains on the bones from slaughterhouses through a biological process which uses enzymes. Conceptually, MPE is comparable to the broth/soup that can be made by cooking bones for several hours, and it has been used by several meat processors over the past decade for flavor improvement and Monosodium glutamate (MSG) reduction. However, recent research has shown that, in addition to flavor improvement, MPE can be used to improve the texture and water-binding capacity of processed meat products such as ham and sausages, and that it can be used to replace some of the salt they contain [15]. The flavor, texture, and water-binding improvement achieved by adding MPE to processed meat products are not fully understood, but some likely explanations are given in Box 1. Further details on MPE production and implementation are given in Box 2. 


\section{Box 1: The nature of enzymes and MPE}

Enzymes are biological catalysts. They are found in all living organisms. They have been used in the production of food products (e.g., cheese, soy sauce, meat tenderization) since ancient times, and are now produced by fermentation and used across a broad range of industries around the world [16]. Enzymes act by cutting biological molecules into pieces like small scissors. The enzymes Protamex ${ }^{\circledR}$ and Flavourzyme ${ }^{\circledR}$ made by Novozymes are proteases which cut meat protein into small pieces of protein (peptides) and free amino acids. The flavor improvement of MPE is likely to be explained by the presence of free amino acids, particularly glutamine, glutamate, cysteine, and methionine, which are known to impact meat flavor. The improved texture and water-binding capacity achieved by adding the MPE to meat products are likely to be driven by two mechanisms: (1) Water binds to hydrophilic side groups of amino acids which come to the surface when proteins are cut into pieces by the enzymes and reorganized; and (2) water is contained in small cavities in the meat which are created when peptides from the MPE bind with the meat during cooking.

\section{Box 2: Production and implementation of MPE}

MPE is produced by treating the meat (left on bones after mechanical meat separation at slaughterhouses) with enzymes in warm water for one hour (approx. $1 \mathrm{~m}^{3}$ water per ton bones; $55^{\circ} \mathrm{C}$ ). The enzymes "cut" the meat into small pieces of protein which is extracted into the water, explaining the name of the product. The enzymes are deactivated by heating after the extraction process by increasing water temperature to $85^{\circ} \mathrm{C}$ in 15 minutes. Processing is conducted in conventional cooking and separation equipment and implementation of MPE production is a simple technical operation.

By producing MPE, profitability for the meat processor is improved because lower-value co-products and trimmings are converted into higher value products. Pay-back period of new MPE production equipment is therefore usually less than one year. Implementation of MPE as alternative to salt in processed meat is likely to be cost neutral or have an insignificant impact on the cost that consumer incur.

MPE content of processed meat products is declared as "partially hydrolyzed (source of protein)" in accordance with United States Department of Agriculture (USDA).

A trial at the Danish Meat Research Institute (DMRI) [15] showed that injection of MPE manufactured by enzymatic hydrolysis of meat with Protamex ${ }^{\circledR}$ and Flavourzyme ${ }^{\circledR}$ had a salt reduction potential of $36 \%$ (from $2.5 \%$ to $1.6 \% \mathrm{NaCl}$ ) without compromising on yield, functionality, and six sensory aspects (color, aroma, taste, saltiness, firmness, and coherency). DMRI estimates that the salt reduction potential can be up to $40 \%$ [31]. 
Novozymes is an innovative biotechnology company with a strong commitment to sustainable development. Novozymes therefore plays a pivotal role in creating not only economic value but also societal benefits by addressing important issues like health, nutrition, and environment: so-called shared value as defined by Porter and Kramer [17]. Though Novozymes does not produce MPE, it has developed the enzymes Protamex ${ }^{\circledR}$ and Flavourzyme ${ }^{\circledR}$ used to produce MPE, and has thus played a central role in developing MPE as an alternative to salt. The purpose of this paper is therefore to assess the socioeconomic impact of MPE if it was implemented broadly in processed meat in the US. The US market has been selected as the geographical focus area because consumption of processed foods is high in the US [18], and salt intake from foods and its effects on health and society are well investigated there.

\section{Method}

The socioeconomic impact of implementing MPE broadly in processed meat (SEI(MPE)) is assessed by calculating the socioeconomic impact per percent of salt intake reduction according to a set of literature references and multiplying this with the salt intake reduction potential of MPE, (SIR(MPE)) and the fraction of the population that can benefit from salt intake reduction, IP.

$$
\text { SEI }(M P E)=\frac{\text { SEI }(\text { total })}{\text { SIR }(\text { total })} \cdot \operatorname{SIR}(\text { MPE }) \cdot \operatorname{IP}
$$

Where:

- SEI (total) is the total socioeconomic effect of reducing sodium intake in the U.S. according to a particular study reported in the literature

- SIR (total) is population-wide sodium intake reduction in the U.S. (\%) according to the same study

- SIR (MPE) is the sodium intake reduction potential of MPE in the U.S. (\%)

- IP is the impacted population according to the considered literature reference (\%)

The factor IP is included to account for the population that can benefit from any sodium intake reduction initiative. Approximately $30 \%$ of the U.S. population consumes less than the recommended dietary limit of sodium (2,400 mg per day) [14] and is therefore excluded from the study. The IP factor is therefore $100 \%-30 \%=70 \%$.

\section{Reference Data Selection}

Several studies have shown that population health and quality of life could be improved and healthcare costs reduced if the sodium intake of a given population was reduced [1,4,9,11,14,19-22]. Based on data and information from a selection of these studies (see Table 1), we attempt to estimate similar socioeconomic impacts on the U.S. population if MPE was implemented broadly in processed meat and salt content in processed meat was subsequently reduced by $36 \%$ as described in the introduction. 
Table 1. Socioeconomic impact in the United States if sodium intake was reduced according to the three selected studies.

\begin{tabular}{|c|c|c|c|c|c|}
\hline \multirow{2}{*}{ Study } & \multirow{2}{*}{$\begin{array}{l}\text { Sodium intake } \\
\text { reduction } \\
\text { SIR (total) } \\
\end{array}$} & \multicolumn{3}{|c|}{ Socioeconomic impact, SEI (total) } & \multirow{2}{*}{$\begin{array}{l}\text { Use in this } \\
\text { study }\end{array}$} \\
\hline & & Category & Type & Quantity & \\
\hline \multirow{4}{*}{$\begin{array}{l}\text { Palar and } \\
\text { Sturm } \\
(2009)\end{array}$} & \multirow{4}{*}{$\begin{array}{l}65 \% \\
(3,400 \text { to } \\
1,200 \mathrm{mg} / \text { day })\end{array}$} & Health & Reduction in cases of hypertension & 17.7 million & Calculation \\
\hline & & $\begin{array}{l}\text { Individual } \\
+ \text { societal }\end{array}$ & QALY $^{\text {a) }}$, year & 496,897 & Calculation \\
\hline & & Societal & QALY worth, billion USD/year & 50.3 & Calculation \\
\hline & & Societal & $\begin{array}{l}\text { Direct healthcare cost savings on } \\
\text { curing hypertension, billion } \\
\text { USD/year }\end{array}$ & 28.3 & Calculation \\
\hline \multirow{6}{*}{$\begin{array}{l}\text { Bibbins- } \\
\text { Domingo } \\
\text { et al. } \\
(2010)\end{array}$} & \multirow{6}{*}{$\begin{array}{l}35 \% \\
\text { (salt reduction } \\
\text { by } 3 \mathrm{~g} / \text { day) }\end{array}$} & Health & Coronary heart diseases averted & $60,000-120,000$ & Calculation \\
\hline & & Health & $\begin{array}{l}\text { Annual number of new cases of } \\
\text { strokes reduced }\end{array}$ & $32,000-66,000$ & Calculation \\
\hline & & Health & $\begin{array}{l}\text { Annual number of new cases of } \\
\text { myocardial infarction reduced }\end{array}$ & $54,000-99,000$ & Calculation \\
\hline & & $\begin{array}{l}\text { Individual } \\
+ \text { societal }\end{array}$ & $\begin{array}{l}\text { Annual number of deaths from } \\
\text { any cases reduced }\end{array}$ & $44,000-92,000$ & Calculation \\
\hline & & $\begin{array}{l}\text { Individual } \\
+ \text { societal }\end{array}$ & QALY, year & $194,000-392,000$ & Validation \\
\hline & & Societal & $\begin{array}{l}\text { Annual healthcare cost savings, } \\
\text { billion USD/year }\end{array}$ & $10-24$ & Validation \\
\hline \multirow{4}{*}{$\begin{array}{l}\text { Smith- } \\
\text { Spangler } \\
\text { et al. } \\
(2010)\end{array}$} & \multirow{4}{*}{$9.5 \%$} & Health & $\begin{array}{l}\text { Annual number of new cases of } \\
\text { strokes reduced }\end{array}$ & 513,885 & Validation \\
\hline & & Health & $\begin{array}{l}\text { Annual number of new cases of } \\
\text { myocardial infarction reduced }\end{array}$ & 480,358 & Validation \\
\hline & & $\begin{array}{l}\text { Individual } \\
+ \text { societal }\end{array}$ & QALY, year & 2.1 million & Validation \\
\hline & & Societal & $\begin{array}{l}\text { Annual direct medical cost } \\
\text { savings, billion USD/year }\end{array}$ & 32.1 & Validation \\
\hline
\end{tabular}

${ }^{\text {a) }}$ QALY: Quality Adjusted Life Year.

A holistic approach is taken in the study and a broad selection of indicators has been implemented: (1) health aspects (reduction in the annual number of new cases of hypertension, coronary heart disease, strokes, myocardial infarction, and deaths); (2) individual aspects (Quality-Adjusted Life Years (QALY); and (3) societal aspects (healthcare cost savings and indirect cost savings from avoided productivity and tax lost due absenteeism). QALY is a measure of disease burden including both the quality and the quantity of life lived [23]. QALY is also the preferred measure of quality of life for cost-effectiveness analysis [24]. This study uses USD 100,000/QALY as its valuation in line with Palar and Sturm[14]. QALY valuation refers to recent dialysis standards updated to 2005-dollars by using the Consumer Price Index [14].

Studies by Palar and Sturm [14], Bibbins-Domingo et al. [9], and Smith-Spangler et al. [11] were selected as references for four main reasons: (1) They are all based on recent data covering the same geographical area (the U.S.); (2) the focus is on population-wide salt reduction strategies; (3) they are 
based on comprehensive datasets covering population subgroups defined by age, sex, and race, as well as health states; and (4) together they cover a broad range of socioeconomic indicators.

We have used Palar and Sturm [14] and Bibbins-Domingo et al. [9] as our primary references. Palar and Sturm had modeled four sodium-reduction scenarios from the national average sodium intake level of 3,400 mg/day to levels of 2,300 (32\%), 1,700 (50\%), 1,500 (56\%), and 1,200 (65\%) mg/day. They used population level data on blood pressure, antihypertensive medication use, and sodium intake, which were then combined with parameters from the literature on sodium effects, costs, and quality of life to yield model outcomes. We have referred to the largest sodium reduction scenario (65\% sodium reduction) because it is the most conservative in our case (see validation in Section 6). Estimates made by Palar and Sturm (2009) [14] are based on dose-response relationships estimated in the 'Meta Study' by He and MacGregor [4]. Healthcare cost savings show the cost reductions expected from a decrease in population blood pressure attributable to reduced population sodium consumption. The annual cost per case of hypertension used in the Palar and Sturm analysis is USD 1,598 [25].

Bibbins-Domingo et al. [9] used the Coronary Heart Disease (CHD) Policy Model to quantify the benefits of potentially achievable, population-wide reductions in dietary salt of up to $3 \mathrm{~g}$ per day (approx. 1,200 mg of sodium per day). They estimated the rates and costs of cardiovascular disease in population subgroups defined by age, sex, and race. In addition, they compared the effects of salt reduction with those of other interventions (like medication) intended to reduce the risk of cardiovascular disease, and determined the relative cost-effectiveness.

The QALY and healthcare cost data from the Bibbins-Domingo et al. [9] study were not considered for our immediate calculations but for validation only. This priority was made to keep the assessment conservative (see validation below). Likewise, the data from Smith-Spangler et al. [11] could have been used for the primary calculations as well, but were reserved for validation to deliver a conservative estimate.

Palar and Sturm [14] and Smith-Spangler et al. [11] provide results as a single figure, whereas Bibbins-Domingo et al. [9] provide intervals. We have adopted the result format from the individual references, and this explains the diverse nature of our results.

Bibbins-Domingo et al. [9] suggests with reference to He-MacGregor [21] that there is a linear relationship between sodium intake reduction within the $0-3$ gram range $(0-1,200 \mathrm{mg}$ sodium) and blood pressure reduction. Blood pressure is linked with coronary heart diseases and subsequent deaths, and therefore economic impacts on society, and we assumed that this also applies to the rest of the socioeconomic indicators considered in the study.

\section{Estimation of Sodium Intake Reduction Potential of MPE in the U.S., SIR(MPE)}

Approximately 35 million tons of meat are consumed in the U.S. every year [26]. Around 22\% of this meat is processed [27] and annual processed meat consumption in the U.S. is around 7.7 million tons. Chicken and pork make up $75 \%$ of the processed meat where MPE is most relevant, and target meat for MPE is in the region of 5.7 million tons. Processed meat contains around 1\% sodium [28] and the nationwide annual total sodium intake with target processed meat is around $5.7 \times 10^{7} \mathrm{~kg}$ per year. With a broad implementation of MPE in processed meat, the sodium intake could be reduced by $36 \%$ (see Introduction), in other words $2.05 \times 10^{7} \mathrm{~kg}$ per year. The total U.S. population is 311 million 
people [29] and the potential daily sodium intake reduction per person is $180 \mathrm{mg}$. The current population-wide sodium intake per person in the U.S. is 3,466 mg/day [26] and the population-wide sodium intake reduction achieved by implementing MPE is therefore estimated to be:

$$
\operatorname{SIR}(\mathrm{MPE})=\frac{\text { Sodium intake saved per person }(\mathrm{mg} / \text { day })}{\text { Current sodium intake per person }(\mathrm{mg} / \text { day })}=\frac{180}{3466}=5.2 \%
$$

\section{Estimation of the Socioeconomic Impacts of MPE}

Estimation of the socioeconomic impacts of broad implementation of MPE in processed meat in the U.S. is determined by Formula (1). SIR(MPE) is derived from the previous section and literature data are derived from Table 1. The results are shown in Table 2.

Table 2. Calculation of the socioeconomic impacts of broad implementation of meat protein extract (MPE) in processed meat and reducing population-wide salt intake in the United States by $5.2 \%$.

\begin{tabular}{|c|c|c|c|}
\hline \multicolumn{2}{|c|}{ Social impact indicator } & \multirow{2}{*}{$\begin{array}{l}\text { Socioeconomic effect } \\
\text { per percent of salt } \\
\text { reduction } \\
\text { a) } \\
\text { SEI(total)/SIR(total) }\end{array}$} & \multirow{2}{*}{$\begin{array}{c}\text { Socioeconomic impact } \\
\text { of MPE } \\
\text { implementation } \\
\text { SEI(MPE) } \\
\end{array}$} \\
\hline Category & Type & & \\
\hline \multirow[t]{5}{*}{ Health aspects } & Reduction in cases of hypertension & 272,307 & $\sim 990,000$ \\
\hline & $\begin{array}{l}\text { Annual reduction in the number of new } \\
\text { cases of coronary heart disease }\end{array}$ & $1,714-3,429$ & $\sim 6,400-13,000$ \\
\hline & $\begin{array}{l}\text { Annual reduction in the number of new } \\
\text { cases of strokes }\end{array}$ & $914-1,886$ & $\sim 3,400-7,000$ \\
\hline & $\begin{array}{l}\text { Annual reduction in the number of new } \\
\text { cases of myocardial infarction }\end{array}$ & $1,543-2,829$ & $\sim 5,700-10,000$ \\
\hline & $\begin{array}{l}\text { Annual reduction in the number of } \\
\text { deaths from any cases }\end{array}$ & $1,257-2,629$ & $\sim 4,600-10,000$ \\
\hline Individual aspects & QALY $^{\text {b) }}$, year & 7,645 & $\sim 28,000$ \\
\hline \multirow[t]{2}{*}{ Societal aspects } & $\begin{array}{l}\text { Annual direct healthcare cost savings, } \\
\text { billion USD/year }\end{array}$ & 0.43 & $\sim 1.6$ \\
\hline & QALY ${ }^{\mathrm{c})}$ worth, billion USD/year & 0.76 & $\sim 2.8$ \\
\hline
\end{tabular}

a) Calculated from data in Table 1; ${ }^{\text {b) }}$ QALY: Quality Adjusted Life Year; ${ }^{\text {c) }}$ 100,000 USD/QALY, see Section 3.

Table 2 shows that even though the sodium reduction achieved by MPE implementation is limited, the projected benefits for people and society is substantial. For instance, approximately 1 million hypertension cases can be avoided and annual direct healthcare costs of USD 1.6 billion can be saved. Likewise, the indirect savings are of around USD 2.8 billion because fewer people get sick and are able to work and pay taxes. Additionally, the number of deaths which can potentially be avoided is up to 10,000 . 


\section{Validation}

This assessment is based on a selection of data from the literature (see Table 1). The results would have been different if other basis data had been used. In the following, we will test the robustness of our estimates by cross-checking with other data as mentioned in Section 3.

Estimation of hypertension cases avoided, annual health cost savings, QALY, and QALY worth were based on a $65 \%$ sodium reduction scenario by Palar and Sturm [14]. Palar and Sturm [14] also had three other salt reduction scenarios which have been assessed based on the same principles as described above. The results show that savings would have been up to $32 \%$ higher if lower salt reduction scenarios had been selected. This indicates that estimates in this study are conservative.

Bibbins-Domingo et al. [9] and Smith-Spangler et al. [11] also assessed QALY savings and healthcare cost savings achieved by salt reduction (see Table 1). Table 3 repeats the results based on Palar and Sturm [14] (reference) and shows to what extent the results would have been different if data from Bibbins-Domingo et al. [9] and Smith-Spangler et al. [11] had been used instead.

Table 3. Validation of estimates of QALY and healthcare costs by comparing the reference results with results based on other studies (validation). Comparisons in brackets refer to the reference.

\begin{tabular}{lccc}
\hline $\begin{array}{l}\text { Social impact } \\
\text { indicator }\end{array}$ & $\begin{array}{c}\text { Palar and Sturm [14] } \\
\text { Reference }\end{array}$ & $\begin{array}{c}\text { Bibbins-Domingo et al. [9] } \\
\text { Validation }\end{array}$ & $\begin{array}{c}\text { Smith-Spangler } \text { et al. [11] } \\
\text { Validation }\end{array}$ \\
\hline QALY, year & 7,645 & $\begin{array}{c}11,200 \\
(46 \% \text { higher })\end{array}$ & $\begin{array}{c}7,809 \\
(2 \% \text { higher })\end{array}$ \\
\cline { 2 - 4 } $\begin{array}{l}\text { Healthcare costs, } \\
\text { billion USD }\end{array}$ & 1.6 & $\begin{array}{c}1.1-2.5 \\
(31 \% \text { lower or } 56 \% \text { higher })\end{array}$ & $\begin{array}{c}18 \\
\text { (approx. 11 times higher })\end{array}$ \\
\hline
\end{tabular}

Table 3 shows how widely QALY estimates and healthcare cost estimates vary. However, estimates based on Palar and Sturm [14] are at the lower end in both cases, and the effects of using MPE do not appear to be overemphasized.

\section{Discussion}

The study uses a range of measurable parameters to provide an indication of the impact on the U.S. population of a population-wide sodium intake reduction facilitated by the use of MPE in processed meat. Some of these impacts are intangible and are measured in QALY. There is an ongoing discussion in the research community regarding methodological issues pertaining to QALY [32] and other cost efficiency measures [33]. We acknowledge that QALY is not a perfect indicator, but we have used it here as it is the most widely used outcome measure for evaluating healthcare interventions and we find that in spite of the limitations, QALY contribute to informed decision for instance at policy level.

This study has focused on the U.S. because health problems related to salt intake are considerable there and also well investigated in the literature. Our results are highly dependent on food consumption patterns, and we recommend that specific results from the study are not extrapolated directly to other countries unless food consumption patterns are similar. However, the general observation that 
considerable individual, health, and societal burdens can be avoided by implementing MPE in countries where salt intake is exceeding health-based recommendations can be transferred without precautions.

Many national initiatives in the U.S. target reducing population sodium intake. NSRI is one such initiative (see Introduction). The goal set under NSRI is to reduce Americans' sodium intake by $20 \%$ to lower the risk of heart attacks, stroke, and premature death. A broad implementation of MPE in processed meat in the U.S. as an alternative to salt would help America to achieve around 25\% of this goal ( $5.2 \%$ divided by $20 \%$ equals $\sim 25 \%$ ).

Every year, common chronic diseases (see Introduction) put a considerable cost burden on the U.S. health system. In 2011, the American Heart Association estimated that in the next two decades, 40\% of the U.S. population is expected to suffer from some form of cardiovascular disease, which will cost around USD 800 billion annually [30]. Seen from this macro perspective, the health and cost savings observed in this study (see Table 2) are small, and salt replacement with MPE can only be seen as one instrument to limit the burden among many others.

\section{Conclusions and Outlook}

This socioeconomic assessment shows that the broad implementation of MPE produced by enzymes in processed meat in the U.S. could reduce population average sodium intake by around $5 \%$. This translates to an average salt intake reduction per person of around $65 \mathrm{~g} /$ year or $450 \mathrm{mg} / \mathrm{day}$. A sodium intake reduction of this magnitude has the potential to reduce the annual number of new cases of hypertension in the U.S. by approx. 1 million, save approximately USD 1.6 billion in healthcare costs, and gain 28,000 QALY worth approximately USD 2.8 billion annually. Validation of results indicates that the above results are relatively conservative and that, for instance, healthcare cost savings could be up to USD 18 billion.

Health and societal problems related to excessive salt intake are widespread today in the U.S. and, unless preventive measures are taken, are expected to grow further in the next two decades. MPE cannot solve the entire problem, but it can be part of the solution. In the NSRI led by New York City Health Department, MPE could contribute to achieving $25 \%$ of the national $20 \%$ salt intake reduction goal by 2014.

MPE is a technology that offers an option to help solve significant social problems without compromising business or on the taste of processed meat. We encourage actors in the food chain to consider this new technology and contribute to sustainable development of our societies.

\section{Acknowledgments}

The authors are grateful to Bent Piil Pedersen and Isaac Ashie from Novozymes A/S, who developed the enzymatic processes for MPE production and provided valuable technical insights for the paper. The study was financed by Novozymes A/S. 


\section{Conflict of Interest}

The authors are employed by Novozymes A/S and have an interest in MPE because Novozymes has fostered MPE as an alternative to salt and deals with enzymes for making it. Novozymes does not produce MPE and does not deal with MPE in any other ways.

\section{References}

1. He, F.J.; MacGregor, G.A. A comprehensive review on salt and health and current experience of worldwide salt reduction programmes. J. Hum. Hypertens. 2008, 23, 363-384.

2. Cobcroft, M.; Tikellis, K.; Busch, J.L.H.C. Salt reduction - a technical overview. Food Aust. 2008, 60, 83-86.

3. World Health Organization (WHO). Primary Prevention of Essential Hypertension. Technical Report 686. WHO: Geneva, Switzerland, 1983; pp. 1-40.

4. He, F.J.; MacGregor, G.A. Effect of longer term modest salt reduction on blood pressure. Cochrane Database Syst. Rev. 2004, 3, 1-53.

5. Henney, J.E.; Taylor, C.L.; Boon, C.S. Strategies to Reduce Sodium Intake in the United States, Committee on Strategies to Reduce Sodium Intake, Institute of Medicine; The National Academies Press: Washington, DC, USA, 2010.

6. Gunn, J.P.; Kuklina, E.V.; Keenan, N.L.; Labarthe, D.R. Sodium intake among adults - United States 2005-2006. Morb. Mortal. Wkly. Rep. 2010, 59, 746-749.

7. Grotto, D.; Zied, E. The standard American diet and its relationship to the health status of Americans. Nutr. Clin. Pract. 2010, 25, 603-612.

8. Edejer, T.T.; Evans, D.; Lowe, J. Some Strategies to Reduce Risk. In The World health Report 2002: Reducing Risks, Promoting Healthy Life; World Health Organization: Geneva, Switzerland, 2002; pp. 99-144.

9. Bibbins-Domingo, K.; Chertow, G.M.; Coxson, P.G.; Moran, A.; Lightwood, J.M.; Pletcher, M.J.; Goldman, L. Projected effect of dietary salt reductions on future cardiovascular disease. N. Engl. J. Med. 2010, 362, 590-599.

10. DeVol, R.; Bedroussian, A. An Unhealthy America: The Economic Burden of Chronic Disease; Milken Institute: Santa Monica, CA, USA, 2007; pp. 1-2.

11. Smith-Spangler, C.M.; Juusola, J.L.; Enns, E.A.; Owens, D.K.; Garber, A.M. Population strategies to decrease sodium intake and the burden of cardiovascular disease - a cost-effectiveness analysis. Ann. Intern. Med. 2010, 152, 481-487.

12. World Health Organization (WHO). Creating an Enabling Environment for Population-Based Salt Reduction Strategies. Report of a joint technical meeting held by WHO and the Food Standards Agency in United Kingdom. WHO Press: Geneva, Switzerland, 2010.

13. Farley, T. Cut the Salt. Get the Facts; The national salt reduction initiative, New York City Department of Health and Mental Hygiene, New York, NY, USA, 2011; pp. 1-5.

14. Palar, K.; Sturm, R. Potential societal savings from reduced sodium consumption in the US adult population. Am. J. Health Promot. 2009, 24, 49-57. 
15. Vestergaard, C. Test of meat protein extract in restructured ham, Trial III. (ref. no. 1379348-10). Danish Meat Research Institute. Danish Technological Institute, Roskilde, Denmark, 2011.

16. Horsmans Poulsen, C.; Kragh, K.M.; Frisbak Sorensen, J.; Grassin, C.; Herweijer, M.; Wilms, J.; de Roos, A.; Borch Soe, J. Enzymes, 3. Food Application. In Ullmann's Encyclopedia of Industrial Chemistry; Wiley-VCH Verlag GmbH \& Co. KGaA: Weinheim, Germany, 2008.

17. Porter, M.E.; Kramer, M.R. Creating shared value - how to reinvent capitalism and unleash a wave of innovation and growth. Harv. Bus. Rev. 2011, January-February, 1-17.

18. Wells, F.H.; Buzby, J.C. Dietary Assessment of Major Trends in U.S. Food Consumption, 1970-2005. Economic information bulletin number 33, Economic Research Service, U.S. Department of Agriculture, Washington, DC, USA, 2008.

19. Goodall, S.; Gallego, G.; Norman, R. Scenario modeling of potential health benefits subsequent to the introduction of the proposed standard for nutrition, health, and related claim. Centre for Health Economics Research \& Evaluation. University of Technology, Sydney, Australia, 2008.

20. Elliott, P.; Stamler, J.; Nichols, R.; Dyer, A.; Stamler, R.; Kesteloot, H.; Marmot, M. Intersalt revisited: further analyses of 24 hour sodium excretion and blood pressure within and across populations. Br. Med. J. 1996, 312, 1249-1253.

21. He, F.J.; MacGregor, G.A. How far should salt intake be reduced? Hypertension 2003, 42, 1093-1099.

22. He, F.J.; MacGregor, G.A. Importance of salt in determining blood pressure in children: Meta-analysis of controlled trials. Hypertension 2006, 48, 861-869.

23. Fernandez, A.; Saameno, J.A.B.; Pinto-Meza, A.; Luciano, J.V; Autonell, J.; Palao, D; Salvador-Carulla, L.; Campayo, J.G.; Haro, J.M.; Serrano, A. Burden of chronic physical conditions and mental disorders in primary care. Br. J. Psychiatry 2010, 196, 302-309.

24. Garber, A.M.; Weinstein, M.C.; Torrance, G.W.; Kamlet, M.S. Theoretical Foundation of Cost-Effectiveness Analysis. In Cost-Effectiveness in Health and Medicine; Gold, M.R., Seigel, J.E., Russell, L.B., Weinstein, M.C., Eds.; Oxford University Press: Oxford, UK, 1996; pp. 176-209.

25. Trogdon, J.G.; Finkelstein, E.A.; Nwaise, I.A.; Tangka, F.K.; Orenstein, D. The economic burden of chronic cardiovascular disease for major insurers. Health Promot. Pract. 2007, 8, 234-242.

26. U.S. Census Bureau. 1377 - Meat consumption by type and country: 2009-2010. Statistical Abstract of the United States, International Statistics, U.S. Census Bureau, Washington, DC, USA, 2011; pp. 860-861.

27. Daniel, C.R.; Cross, A.J.; Koebnick, C.; Sinha, R. Trends in meat consumption in the USA. Public Health Nutr. 2011, 14, 575-583.

28. Bender, A. Meat and Meat Products in Human Nutrition in Developing Countries. Food and Nutrition Paper 53. Food and Agriculture Organization of the United Nations (FAO), Rome, Italy, 1992.

29. Mackun, P.; Wilson, S. Population Distribution and Change: 2000 to 2010 (C2010BR-01). 2010 Census briefs, U.S. Census Bureau, Washington, DC, USA, 2011.

30. Heidenreich, P.A.; Trogdon, J.G.; Khavjou, O.A.; Butler, J.; Dracup, K.; Ezekowitz, M.D.; Finkelstein, E.A.; Hong, Y.; Johnston, S.C.; Khera, A.; et al. Forecasting the future of cardiovascular disease in the United States. Circulation 2011, 123, 933-944. 
31. Sørensen, R. Tomorrow's consumers will expect healthier food - Is your company ready? October Newsletter on Product Development. Danish Meat Research Institute (DMRI), Danish Technological Institute, Roskilde, Denmark, 2010.

32. Lipscomb, J.; Drummond, M.; Fryback, D.; Gold, M.; Revicki, D. Retaining, and enhancing, the QALY. Value Health 2009, 12, S18-S26.

33. Mehrez, A.; Gafni, A. Preference based outcome measures for economic evaluation of drug interventions: Quality adjusted life years (QALYs) versus healthy years equivalents (HYEs). Pharmacoeconomics 1992, 1, 338-345.

(C) 2012 by the authors; licensee MDPI, Basel, Switzerland. This article is an open access article distributed under the terms and conditions of the Creative Commons Attribution license (http://creativecommons.org/licenses/by/3.0/). 